\title{
PENGGUNAAN MEDIA ANIMASI KOMPUTER PADA PEMBELAJARAN LAJU REAKSI UNTUK MENINGKATKAN HASIL BELAJAR KIMIA MELALUI DI KELAS XI IPA SMA NEGERI 1 SIBOLGA
}

\author{
Nurmariana Okto Delima Sinaga \\ Sekolah Menengah Atas Negeri 1 Sibolga, Sumatera Utara \\ nurmarianasinagatujuhsatu71@gmail.com
}

\begin{abstract}
Abstrak: Tujuan penelitian tindakan kelas ini adalah: (1) Meningkatkan aktifitas belajar siswa pada materi reaksi redoks menggunakan metode pembelajarn tutor sebaya; (2) Meningkatkan hasil belajar siswa pada meteri reaksi redoks menggunakan metrode pembelajarn tutor sebaya. Hasil penelitian ini menunjukkan bahwa: (1) Pembelajaran tutor sebaya dapat memeperbaiki aktifitas belajar siswa. Hasil dari observasi terhadap seluruh aktifitas siswa pada siklus I dan siklus II menunjukkan rata-rata aktifitas siswa mengalami peningkatan; (2) Pembelajaran tutor sebaya dapat memperbaiki hasil belajar siswa. Hasil dari analisis terhadap nilai rata-rata kelas berdasarkan perbandingan antara kelompok pada siklus I dan siklus II dan anlisis terhadap nilai individu siswa yang diperoleh dari tes akhir pembelajarn mengalami peningkatan
\end{abstract}

Kata Kunci: peningkatan hasil belajar kimia, media animasi computer, laju reaksi

\begin{abstract}
The purpose of this class action research are: (1) Improving the learning activities of students on the material using the redox reaction pembelajarn method of peer tutoring; (2) Improve student learning outcomes in a redox reaction using METRODE meteri pembelajarn peer tutors. The results of this study indicate that: (1) Learning Touch ups can peer tutor students' learning activities. The results of observations of all activities of the students in the first cycle and the second cycle shows the average activity of students has increased; (2) Learning peer tutors can improve student learning outcomes. Results from the analysis of the average value of the class based on the comparison between the groups in the first cycle and the second cycle and anlisis the individual values obtained from tests students end pembelajarn increased
\end{abstract}

Keywords: learning outcome chemistry, computer animation media, the reaction rate

\section{PENDAHULUAN}

Penelitian ini dilatar belakangi oleh adanya upaya untuk meningkatkan aktifitas dan hasil belajar siswa dalam mata pelajaran kimia. Berdasarklan data yang ada bahwa siswa yang telah mencapai kompetensi pada materi redoks kelas X-MIPA5 semester II tahun pelajaran 2013/2014 hanya mencapai kurang dari 50\% (sebelum remedial). Kondisi ini cukup mengkwatirkan mengingat bahwa belajar tuntas pada Kurikulum Tingkat Satuan Pendidikan (KTSP) untuk mata pelajaran kimkia di SMA Negeri 1 Sibolga menetapkan Kriteria Ketuntasan Minimal (KKM) 60. sedangkan aspek ketuntasan belajar secara klasikal harus mencapai ketuntasan belajar $85 \%$ dari total jumlah siswa mencapai nilai keriteria Ketuntasan Minimal 60. selanjutnya yang paling mengkhwatirkan jika salah satu kompetensi atau mata pelajaran kimia tidak mencapai nilai standar siswa tersebut tidak dapat melanjutkan kejenjang berikutnya dalam arti kriteria kenaikan kelas / kelulusan nilai mata pelajaran harus lulus $100 \%$.

Salah satu kelemahan yang terjadi pada mata pelajaran kimia kelas X-MIPA5 adalah pencapaian kompetensi dalam materi reaksi redoks. Akibatnya pendalaman materi kurang, yang menyebabkan pengetahuan siswa menjadi dangkal. Hal tersebut juga ditunjang oleh lemahnya keinginan siswa untuk berdiskusi, berlatih, bertanya baik antar teman ataupun bertanya langsung kepada guru sehingga munculah sikap masa bodoh, jenuh, tidak kretaif dan pada akhirnya prestasi belajar menurun, fenomena lainnya adalah ketergantungan terhadap guru yang masih mendominasi sikap siswa.

Khusunya dalam kompetensi reaksi redoks dan umumnya mata pelajaran kimia perlu diupayakan penerapan strategi pembelajaran yang mendorong siswa untuk lebih kreatif, dan tertantang untuk belajar. Salah satu strategi pembelajaran yang dianggap 
relevan dan diyakini dapat memperbaiki kualitas pembelajaran dan hasil belajar siswa adalah metode pembelajaran tutor sebaya.

\section{Aktifitas Belajar}

Belajar menurut Hamalik (2004:27) diartikan sebagai modifikasi atau memperteguh kelakuan melalui pengalaman. Belajar merupakan suatu proses aktifitas dan bukan suatu hasil tujuan. Proses belajar diartikan upaya guru bersama siswa pada situasi yang telah ditentukan untuk mencapai yujuan yang diinginkan. Keterlibatan siswa dalam pembelajaran merupakan suatu yang sangat mendasar, karena pada prinsipnya belajar adalah proses dimana peserta didik mampu mencari, menemukan dan mengembangkan pengetahuan secara aktif, mandiri dan bertanggung jawab. Beberapa ahli menyatakan bahwa belajar adalah suatu perilaku, pada saat belajar responnya menjadi baik, sebaliknya pada saat tidak belajar maka responnya akan menurun. (Skiner dalam Dimyati dan Mudjiono, $2002: 10$ )

Aktifitas belajar merupakan rangkaian kegiatan yang dilakukan baik oleh siswa maupun guru dalam suatu proses pembelajaran yang dilakukan sengaja, terencana dan terukur, sengaja diartikan sebagai suatu kegiatan yang dilakukan berdasarkan suatu tujuan dan bukan berdasarkan hobi semata. Terencana diartikan sebagai suatu desain, wahana atau media yang didesain untuk mencapai tujuan-tujuan yang telah ditentukan dimana memuat persoalan dan bagaimana tujuan itu dapat dicapai. Terukur adalah bahwa seluruh kegiatan yang dilakukan dapat dikategorikan, dinilai dengan ukuran yang telah ditentukan. Setiap siswa mengharapkan keberhasilan dalam belajar. Keberhasilan belajar tidak akan tercapai begitu saja tanpa diimbangi dengan aktifitas belajar yang baik.

Aktifitas belajar nerupakan rangkaian kegiatan yang dilakukan individu untuk mencapai perubahan tingkah laku. Seperti yang dilakukan individu untuk mencapai perubahan tingkah laku. Seperti yang diungkap Sudirman (1992:95) dalam belajar sangat diperlukan aktifitas, tanpa aktifitas tidak mungkin belajar akan berlangsung dengan baik. Aktifitas dalam belajar mengajar merupakan rangkaian kegiatan yang meliputi keaktipan siswa dalam mengikuti pelajaran, bertanya tentang hal yang belum jelas, mencatat, mendengar, berfikir, membaca dan segala kegiatan yang dilakukan yang dapat menunjang prestasi belajar.

\section{Hasil belajar}

Hasil belajar merupakan efek dari proses belajar yang terjadi. Karena itu hasil belajar akan tercapai dengan baik jika proses belajar juga baik, hasil belajar siswa diperoleh setelah berakhir prose belajar mengajar. Belajar merupakan kegiatan inti dari kegiatan pendidikan. Untuk itu kegiatan belajar harus digarap dengan baik dan sungguh-sungguh oleh lembaga penyelenggara pendidikan, karena kegagalan dalam mengelola kegiatan belajar berarti pula ketidak berhasilan pendidikan dalam mewujudkan tujuan pendidikan

Menurut Dimyati (1999;3) mengatakan bahwa hasil belajar merupakan hasil dari suatu interaksi tindak belajar dan mengajar. Dari sisi guru tindakan mengajar diakhiri dengan proses evaluasi hasil belajar dari sisi siswa hasil belajar merupakan puncak proses belajar.

Winkel ( 1996;53) berpendapat bahwa belajar merupakan suatu aktifitas mental/psikis yang berlangsung dalam interaksi aktif dengan lingkungan yang menghasilkan perubahanperubahan dalam pengetahuan, pemahaman, keterampilan, nilai, sikap yang dimiliki oleh suatu individu.

Lefrancois(1995:5) mengemukan bahwa belajar adalah suatu perubahan tingkah laku yang relatif permanen sebagai hasil pengalaman. pendapat yang sama dikemukan oleh Good dan Brpphy (1990:58) bahwa terjadinya belajar ditunjukan oleh adanya perubahan tingkah laku yang relatif permanen sebagai hasil dari pengalaman. Proses perubahan itu secara relatif untuk memperoleh perubahan permanent dalam pemahaman, sikap pengetahuan, informasi, kemampouan dan keterampilan melalui pengelaman. Sementara itu Gagne (1972;2) berpendapat bahwa belajar diartikan sebagai perubahan watak dan kecakapan manusia yang berlangsung dalam pariode waktu yang lama, yang bukan merupakan proses pertumbuhan. Jenis perubahan tersebut ditunjukkan dengan adanya suatu perubahan tingkah laku dan kecakapan. Dari beberapa pendapat sebagai mana dikemukan diatas, nampak adanya kesamaan pengetian bahwa yang dimaksud belajar adalah suatu proses perubahan tingkah laku. Perubahan tingkah laku itu bukan dating tanpa didasari atau dating dengan sendirinya, melainkan diperoleh melalui latihan atau pengelaman. Artinya adanya adanya suatu usaha berupa aktifitas yang menghasilkan perubahan pada diri individu yang belajar. Suatu hal yang perlu 
dikemukan disini adalah bahwa tidak semua perubahan yang terjadi pada individu dapat digolongkan sebagai belajar. Gagne (1977;3) berpendapat bahwa perubahan yang dimaksud berbeda dengan jenis perubahan karena pertumbuhan, seperti halnya tinggi badan atau perkembangan otak melalui latihan. Bertolak dari pengertian ini maka hasil belajar merupakan hasil kegiatan dalam bentuk pengetahuan sebagai akibat dari perlakuan atau pembelajaran yang dilakukan siswa, atau dengan kata lain hasil belajar merupakan apa yang diperoleh siswa.

Prestasi belajar merupakan suatu Indikator yang menunjukkan sejauh mana dengan kegiatan belajar mengajar telah mencapai tujuan yang telah ditetapkan. Hasil belajar yang diukur menurut Kurikulum Berbasis Kompetensi meliputi kognitif, efektif dan psikomotor. Kwalitas prosers belajar mengajar dapat dilihat dari segi proses hasil belajar (Mulyasa, 2002;100). Dari hasil proses pembelajaran dikatakan berhasil dan berkwalitas apabila seluruhnya atau sebagian besar $(75 \%)$ siswa terlibat secara aktif, baik, fisik, mental maupun sosial dalam proses pembelajaran, disamping menunjukkan kegairahan belajar yang besar serta percaya diri sendiri. Sedangkan dari segi hasil proses pembelajaran dikatakan berhasil apabila terjadi perubahan tingkah laku yang positif pada siswa.

\section{Tutor Sebaya}

Pembelajaran tutor sebaya adalah cara atau teknik penyajian bahan pelajaran yang akan digunakan guru melalui sumber belajar tutor sebaya yakni siswa yang lebih pandai memberikan bantuan belajar kepada temanteman sekelasnya di sekolah. Menurut Dedi Supriyadi $(1983 ; 36)$ bahwa tutor sebaya adalah seorang atau beberapa siswa yang ditunjuk dan ditugaskan untuk membantu siswa yang mengalami kesulitan belajar. Tutor diambil dari kelompok yang prestasinya lebih tinggi.

Istilah tutor sebaya menurut kamus besar Bahasa Indonesia yaitu Tutor adalah orang yang memeberi pelajaran kepada seseorang atau sejumlah kecil siswa, pengajaran oleh tutor. Menurut Ischak ( 1997 ; 45) mengatakan bahwa adakalanya seorang siswa yang lebih mudah menerima bantuan dari teman-temannya dari pada gurunya, karena dengan temannya, apalagi teman akrab ia tidak punya rasa engan, rendah diri dan sebagainya untuk bertanya ataupun minta bantuan/diberi bantuan.

Dengan metode tutor sebaya guru dibantu oleh siswa yang telah memahami pelajaran. Maka manfaatkan siswa agar dapat meningkatkan pemahaman dan penguasaan bahan pelajaran. Nasution, (1978;43-44)

Menurut Muh. Surya (1981:164) yang dimaksud dengan tutor sebaya adalah seseorang atau beberapa murid yang ditunjuk dan ditugaskan untuk membantu murid-murid tertentu yang mengalami kesulitan. Ada beberapa kelebihan dan kebaikan dalam kegiatan tutor sebaya, diantaranya :

1. Adakalahnya hasil lebih baik bagi beberapa anak yang mempunyai perasaan takut atau engan pada gurunya.

2. Bagi Tutor, pekerjaan tutor akan mempunyai akibat memperkuat konsep yang akan dibahas. Dengan memeberitahukan kepada siswa yang lain, maka seolah-olah menelaah serta menghafalkan kembali.

3. Bagi tutor merupakan kesempatan untuk melatih diri untuk memegang tanggung jawab dalam mengembangkan suatu tugas dan melatih kesabaran.

4. Memperkuat hubungan antar siswa sehingga mempertebal perasaan. (Arikunto, 1986;64)

Disamping kebaikan tersebut, ada kesulitan dalam melaksanakan tutor sebaya ini diantaranya disebabkan :

1. Siswa yang seringkali belajar kurang serius karena hanya berhadapan dengan kawankawannya sehingga hasilnya kurang memuaskan

2. Ada beberapa anak merasa malu bertanya karena takut rahasianya diketahu oleh kawannya.

3. Pada kelas-kelas tertentu pekerjaan tutoring ini sukar dilaksanakan karena perbedaan kelamin antara tutor dengan siswa yang dibimbing

4. Bagi guru sukar untuk menentukan seseorang tutor yang tepat bagi seseorang atau beberapa orang siswa yang bombing.

5. Tidak semua siswa yang pandai atau cepat tempo belajarnya dapat menerangkan kembali kepada kawan-kawannya (Arikunto, 1987;64)

Dalam pelaksanaan tutor sebaya, guru perlu memberikan pengarahan dan petunjuk tertulis kepada tutor tentang materi yang akan diajarkan dan cara penyampaiannya sebelum mulai kegiatan pembelajaran 


\section{Aplikasi Metode Tutor Sebaya}

Tutor sebaya merupakan model pembelajaran dimana siswa atau beberapa siswa yang dapat dipandang lebih baik dalam penguasaan materi diberikan tugas untuk memberikan materi pembelajaran pada kawankawannya. Metode ini merupakan aplikasi prinsip pengajaran berbasis aktifitas siswa. Pada pelaksanaannya paling diuatamakan adalah bagai mana guru merancang rencana pembelajaran yang merupakan bagian yang harus dilaksanakan siswa pada saat tutoring dengan kawannya. Pemberian tugas pada metode ini adalah hendaknya sebagai rencana pembelajaran yang akan dilakukan oleh guru. tugas yang baik tentunya memenuhi beberapa persyaratan yakni tujuan jelas, waktunya ditentukan, materi ditentukan, subjek yang jelas dan evaluasinya diinformasikan kepada siswa.

Tujuan dari metode tutor sebaya adalah untuk memperoleh hasil belajar yang optimal yang disebabkan oleh aktifitas siswa dalam proses belajar. Keterlibatan siswa sebagai salah satu sumber belajar menjadi hal yang berbeda dan merancang tumbuhnya minat belajar siswa. Minat belajar siswa akan tumbuh dan tertantang karena ada beberapa kemungkinan pada setiap siswa untuk dapat menjadi tutor pada pertemuan berikutnya.

Langkah - langkah pelaksanaan tutor sebaya sebagai berikut :

1. Membuat kelompok dimana siswa yang memiliki kemampuan lebih menyebar pada kelompok yang ada.

2. Memilih siswa yang akan menjalankan tutoring

3. Menentukan Materi tutoring, jadwal dan waktu pelaksanaan.

4. Menyusun rencana pembelajaran yang dibuat dengan format dapat dipahami siswa.

5. Memberikan petunjuk dan penjelasan tentang bagaimana jalannya pembelajaran tutoring sebaya pada siswa.

6. Menyusun format evaluasi kegiatan dan pertanyaan diajukan siswa.

Dari penelitian yang dilakukan teman guru di SMA Negeri 1 Sibolga menunjukkan bahwa siswa yang diberikan dengan metode tutor dan memiliki minat yang amat tinggi dalam mengikuti pembelajaran yang ditujukkan dengan meningkatkan kemampuan : bertanya, menjawab, memilih, menetukan dan menerangkan konsep kimia dengan baik. Dengan demikian yang dirancang dengan baik secara cukup berarti dapat memberikan kontribusi terhadap peningkatan minat siswa terhadap mata pelajaran kimia.

Rumusan masalah penelitian ini adalah: (1) Apakah penerapan metode tutor sebaya dapat meningkatkan aktifitas belajar siswa dalam pembelajaran reaksi redioks kelas XMIPA5 SMA Negeri 1 Sibolga? ; (2) Apakah penerapan metode tutor sebaya dapat meningkatkan hasil belajar siswa dalam pembelajaran reaksi redoks kelas X-MIPA5 SMA Negeri 1 Sibolga ?. Adapun hipotesis penelitian adalah pembelajaran tutor sebaya dapat meningkatkan aktifitas dan hasil belajar siswa kelas X-MIPA5 SMA Negeri 1 Sibolga pada materi reaksi redoks. Yang menjadi Indikator keberhasilan tindakan adalah aktifitas dan hasil belajar siswa kelas X-MIPA5 SMA Negeri 1 Sibolga mengalami peningkatan.

\section{METODE PENELITIAN}

Penelitianm tindakan ini dilakukan di SMA Negeri 1 Sibolga. Adapun subyek penelitian adalah siswa kelas X-MIPA5. penelitian ini termasuk kedalam penelitian tindakan kelas. Penelitian ini akan dilaksanakan pada dalam dua siklus dan setiap siklus terdiri dari dua kali pertemuan.

Dalam penelitian ini metode yang digunakan adalah metode penelitian tindakan kelas yaitu penelitian yang didasarkan kepada suatu pencermatan terhadap kegiatan belajar berupa suatu tindakan, yang sengaja dimunculkan dan terjadi dalam sebuah kelas secara bersama. Tindakan tersebut diberikan oleh guru atau dengan arahan dari guru yang dilakukan oleh siswa. Maka yang terkandung dalam penelitian tindakan kelas ini adalah suatu bentuk penelitian yang bersifat reflektif dengan melakukan tindakan-tindakan tertentu agar dapat memperbaiki dan meningkatkan proses belajar yang pada akhirnya dapat meningkatkan hasil belajar dan aktifitas siswa.

Penelitian tindakan kelas ini terbagi dalam dua siklus pembelajaran. Masing-masing siklus terdiri dari kegiatan penyampaian materi, diskusi kelompok yang dibimbing oleh seorang tutor, dilanjutkan dengan presentasi kelas yang diwakili oleh tutor dan evaluasi setelah pembelajaran.

Diantara dua siklus dilakukan refleksi dengan tujuan untuk mengevaluasi proses pembelajaran yang dilakukan untuk memperbaiki pembelajaran selanjutnya. Adapun tahapan-tahapan yang dilakukan dalam penelitian tindakan ini terdiri dari empat 
komponen yang meliputi : (1) perencanaan (planning). (2) Tindakan (acting). (3) Observasi (observing), dan (4) refleksi (reflecting).

Subyek yang diambil dalampenelitian ini adalah siswa kelas X-MIPA5 SMA Negeri 1 Sibolga pada materi reaksi redoks. Jumlah siswa terdiri 35 orang dan dibagi dalam 7 kelompok. Dengan masing-masing kelompok 5 orang berikut dengan tutornya. Rata-rata kemampuan pada kelas ini adalah hiterogen.

\section{Metodologi Pengumpulan Data}

Data yang diperoleh dari pertemuan ini adalah hasil observasi aktifitas pembelajaran siswa, catatan lapangan dari hasil evaluasi pasca pembelajaran tiap siklus. Secara umum data yang diperoleh berupa data kualitatif dan kuantitatif yang meliputi.

\section{Data tes setelah tindakan siklus I dan siklus II}

Tes diadakan setelah tindakan selesai dilakukan pada setiap siklus. Tes ini diberikan dalam bentuk pilihan ganda yang dilakukan pada setiap siklus. Hasil tes ini berupa data kuantitatif yang diambil pada setiap siklus. Tes ini dimaksudkan agar setiap berakhirnya pelaksanaan siklus dapat diketahui kemajuan dan perkembangan hasil belajar siswa. Dengan demikian hasil yang diperoleh dapat menjadi acuan pertimbangan bahan refleksi, untuk merencanakan pelaksanaan siklus berikutnya. Untuk evaluasi pasca pembelajaran dilakukan penilaian dengan rentang $0-100$.

\section{Hasil Observasi terhadap proses pelaksanaan pembelajaran.}

Observasi dilaksanakan dengan cara mengamati seluruh aktifitas siswa selama proses pembelajaran berlangsung. Untuk aktifitas belajar siswa dilakukan dengan pensekoran berdasarkan aktifitas-aktifitas yang muncul dengan cara menghitung prosentase dari tiap-tiap aktifitas selama pembelajaran dengan total skor $100 \%$. Aktifitas tersebut diobservasi tiap 10 menit sekali selama pembelajaran. Data tingkat aktifitas belajar ini kemudian dikelompokkan menurut kriteria aktifitas pada tabel2 di bawah ini :

Tabel 2. Kriteria aktifitas

\begin{tabular}{|c|c|}
\hline $\begin{array}{c}\text { Skor Rata-Rata } \\
\text { Aktifitas }(\%)\end{array}$ & Kriteria Aktifitas \\
\hline $76-100$ & Sangat Aktif \\
\hline $51-75$ & Aktif \\
\hline
\end{tabular}

\begin{tabular}{|c|c|}
\hline $\begin{array}{c}\text { Skor Rata-Rata } \\
\text { Aktifitas }(\%)\end{array}$ & Kriteria Aktifitas \\
\hline $26-50$ & Cukup aktif \\
\hline $0-25$ & Kurang aktif \\
\hline
\end{tabular}

1) Jurnal Harian

Catatan harian adalah jurnal harian yang merupakan alat bantu perekam yang paling sederhana, catatan ini dapat dijadikan pertimbangan bagi pelaksanaan pembelajaran berikutnya. Dalam catatan harian ini dimasukkan juga catatan mengenai kegiatan guru yang dilaksanakan di dalam kelas. Hal ini sejalan dengan pendapat tim pelatih PGSM $(1999 ; 57)$ yang menyatakan bahwa jurnal harian merupakan semacam catatan harian. Catatan harian ini akan merekam semua kegiatan dalam proses pembelajaran yang tidak terekam dalam lembaran observasi baik berupa perilaku siswa/kegiatan guru yang berlangsung dalam kelas maupun permasalahan yang dapat dijadikan pertimbangan bagi langkah berikutnya. Hal ini sesuai dengan pendapat Madya (1994;35) bahwa catatan harian ini akan memuat observasi, perasaan, reaksi, penafsiran, refleksi, dugaan, hipotesis dan penjelasan.

2) Foto

Untuk merekam aspek kegiatan kelas, aktifitas siswa dan memperjelas data Dari hasil observasi maka dalam penelitian ini digunakan alat perekam lainnya yaitu foto. Menurut Madya (1994;39) bahwa foto digunakan untuk merekam peristiwa penting , serta karena daya tarik foto dapat diacu dalam wawancara berikutnya dan diskusi tentang data.

\section{HASIL DAN PEMBAHASAN}

Penelitian tindakan kelas ini dilaksanakan pada kelas X-MIPA5 SMA Negeri 1 Sibolga yang telah mendapatkan materi redoks. Penelitian ini dilakukan dalam 2 siklus. Setiap siklus terdiri dari 2 ( dua ) kali pertemuan. Siklus I dan siklus II. secara garis besar kegiatan yang berkaitan dengan tutor sebaya akan dilakukan untuk setiap kali pertemuan. Setiap kali pertemuan sebelumnya diberikan tugas untuk tutoring kepada masingmasing kelompok dengan terlebih dahulu menentukan tutor sebaya pada setiap kelompok.

Pada Penelitian ini dilakukan tes kemampuan untuk menentukan siswa yang prestasinya baik sebagai tutor sebaya. Dari hasil 
tes kemampuan maka diperoleh 7 orang yang mempunyai kemampuan lebih dari pada temantemannya dan kemudian dibuat 7 kelompok. Masing-masing kelompok diberi materi yang berbeda. Secara garis besar kegiatan ini dilakukan sebagai berikut :

(1) Pada mulanya siswa diberi materi ajar untuk mengkaji konsep-konsep esensial.

(2) Setiap kelompok diharapkan untuk mempresentasikan materi ajar yang sudah disiapkan, dengan cara setiap siswa dari 7 orang yang terpilih untuk menjadi tutor.

(3) Guru mengawasi jalannya pembelajaran yang sedang berlangsung dan memastikan setiap siswa atau setiap kelompok melaksanakan tahapan sesuai dengan yang telah ditentukan.

(4) Setiap siswa baik secara individu maupun kelompok diwajibkan membuat kesimpulan dan penjelasan dengan cara diskusi dan mempresentasikan di kelas

(5) Guru membahas hal-hal yang belum terungkap selama kegiatan tutoring dilakukan.

(6) Siswa diberikan kesempatan bertanya tentang hal-hal yang belum dipahami

(7) Pada akhir kegiatan belajar mengajar guru menyimpulkan materi yang telah diberikan

(8) Guru memberikan beberapa pertanyaan kepada siswa untuk mengecek penguasaan materi dan ketuntasan belajar.

Kegiatan yang berlangsung selama proses belajar mengajar ditampilkan pada gambar, pada gambar tersebut divisualisasikan guru sedang memberikan penjelasan mengenai reaksi redoks pada siswa kelas X-MIPA5 SMA Negeri 1 Sibolga

Pada langkah berikutnya, dibuat kelompok-kelompok belajar. Dari jumlah siswa kelas X-MIPA5 yang berjumlah 35 orang dibuat menjadi 7 kelompok belajar. Setiap kelompok terdiri dari 5 orang berikut dengan tutornya. Rata-rata kemampuan pada kelas ini adalah hiterogen. Aktifitas siswa selama kerja dalam kelompok diamati oleh guru dan dapat dilihat pada gambar2. pada gambar tersebut ditunjukkan aktifitas siswa dalam berdiskusi dengan tutor sebayanya.

Pelaksanaan tindakan siklus II. Pada siklus ke 2 dilakuakn setelah diadakan refleksi dari semua kegiatan yang sama seperti kegiatan yang dilakukan pada siklus I. pada siklus 2 ini cendrung pada arah perbaikan proses, sehingga hasil-hasil belajar terjadi peningkatan. Indikator keberhasilan tindakan untuk prestasi hasil belajar siswa melalui metode pembelajaran tutor sebaya jika lebih dari $75 \%$ siswa memperoleh nilai diatas 65 .

Dari penelitian yang dilakukan teman guru di SMA Negeri 1 Sibolga tahun 2014 menunjukkan bahwa siswa yang diberikan dengan metode tutor dan memiliki minat yang amat tinggi dalam mengikuti pembelajaran yang ditunjukkan dengan meningkatnya kemampuan : bertanya, menjawab, memilih, menentukan dan menerapkan konsep-konsep kimia dengan baik dengan demikian yang dirancang dengan baik secara cukup berarti dapat memberikan kontribusi terhadap peningkatan minat siswa terhadap mata pelajaran kimia.

\section{Hasil Belajar siswa}

Pelaksanaan penelitian tindakan kelas ini dilaksanakan dalam dua siklus. Siklus I dilaksanakan dalam dua kali pertemuan. setiap siklus terdiri dari dua pertemuan dan satu kali tes, sehingga total pertemuan enam kali pertemuan.

Kegiatan penelitian ini berupaya untuk mengungkapkan hasil pembelajaran kimia pada materi redoks dengan menggunakan pembelajaran tutor sebaya. Hasil belajar siswa dalam menjawab soal pada akhir siklus I dapat ditampilkan pada tabel 3 sebagai berikut :

Table 3. Rekapitulasi Perolehan Nilai Pemahaman Pada siklus I

\begin{tabular}{|c|c|c|c|c|}
\hline NO & NILAI & JUMLAH SISWA & PERSENTASE & Rata-rata Nilai \\
\hline 1 & $\geq 80$ & 3 & $8,57 \%$ & \multirow{2}{*}{6} \\
\cline { 1 - 3 } 2 & $70-80$ & 5 & $14,29 \%$ & \multirow{2}{*}{62,43} \\
\hline 3 & $60-70$ & 5 & $14,29 \%$ & \\
\hline 4 & $50-60$ & 20 & $57,14 \%$ & \\
\hline 5 & $\leq 50$ & 2 & $5,71 \%$ & \\
\hline & Jumlah & 35 & $100 \%$ & \\
\hline
\end{tabular}

Berdasarkan data tes pada siklus I, secara umum hasil tes rata-rata menunjukkan peningkatan. Hasil belajar pertemuan 1 dan pertemuan 2 maka diperoleh data 3 orang mendapat 
nilai $\geq 80(5,57 \%), 5$ orang mendapat nilai $70-80(14,29 \%), 5$ orang mendapat nilai $60-70$ $(14,29 \%), 20$ orang mendapat nilai $50-60(57,14 \%)$ dan 2 orang mendapat nilai $\leq 50(5,71 \%)$. Rata-rata perolehan nilai pemahaman kemampuan siswa pada siklus I adalah 62.43. Siklus II dilaksanakan 2 (dua) kali pertemuan. pada setiap akhir pertemuan dilakukan tes. Adapun hasil perolehan tes dapat dilihat pada tabel 4 berikut :

Table 4. Rekapitulasi Perolehan Nilai Pemahaman Pada siklus II

\begin{tabular}{|c|c|c|c|c|}
\hline NO & NILAI & JUMLAH SISWA & PERSENTASE & Rata-rata Nilai \\
\hline 1 & $\geq 80$ & 5 & $14,29 \%$ & \multirow{2}{*}{73,29} \\
\hline 2 & $70-80$ & 19 & $54,29 \%$ & \multirow{2}{*}{} \\
\cline { 1 - 3 } 3 & $60-70$ & 6 & $17,14 \%$ & \\
\hline 4 & $50-60$ & 4 & $11,49 \%$ & \\
\hline 5 & $\leq 50$ & 1 & $2,86 \%$ & \\
\hline & Jumlah & 35 & $100 \%$ & \\
\hline
\end{tabular}

Berdasarkan data tes pada siklus II, secara umum hasil tes rata-rata menunjukkan peningkatan. Hasil belajar pada siklus II 5 orang mendapat nilai $\geq 80(14.29 \%)$, 19 orang mendapat nilai $70-80(54,29 \%), 6$ orang mendapat nilai $60-70(17,14 \%), 4$ orang mendapat nilai $50-60(11,49 \%)$ dan 1 orang mendapat nilai $\leq 50 \quad(2.86 \%)$. Rata-rata perolehan nilai pemahaman kemampuan siswa pada siklus II adalah 73,29. Berdasarkan hasil belajar pada siklus I dan siklus II menunjukkan adanya peningkatan.
Aktifitas Belajar siswa
Untuk mengamati aktifitas belajar siswa pada siklus I dan Siklus II dilakukan dengan bantuan seorang guru yang bertindak sebagai observer. Lembar pengamatan mencakup materi pengamatan : (1) mengemukan pendapat; (2) bertanya pada tutor; (3) berdebat; (4) memecahkan masalah; (5) diskusi; (6) memberikan saran.
Semua aktifitas belajar siswa tersebut terangkum dalam tabel 5 sebagai berikut :

Tabel 5. Aktifitas Selama Tindakan Siklus I

\begin{tabular}{|c|c|c|c|c|c|c|}
\hline \multirow[b]{2}{*}{ No } & \multirow[b]{2}{*}{ Aktifitas yang dilakukan } & \multicolumn{4}{|c|}{ SIKLUS I } & \multirow[b]{2}{*}{$\begin{array}{c}\text { Peningkatan } \\
(\%)\end{array}$} \\
\hline & & $\begin{array}{l}\text { Pertemua } \\
\text { n } 1\end{array}$ & $(\%)$ & $\begin{array}{l}\text { Pertemua } \\
\text { n } 2\end{array}$ & $(\%)$ & \\
\hline 1 & Mengemukan pendapat & 10 & 28.57 & 12 & 34.28 & 5.71 \\
\hline 2 & Bertanya & 12 & 34.28 & 15 & 42.86 & 8.58 \\
\hline 3 & Berdebat & 6 & 17.14 & 10 & 28.57 & 11.43 \\
\hline 4 & Memecahkan masalah & 15 & 42.86 & 18 & 51.43 & 8.57 \\
\hline 5 & Diskusi & 10 & 28.57 & 15 & 42.86 & 14.29 \\
\hline \multirow[t]{3}{*}{6} & Memberi saran & 12 & 34.28 & 16 & 45.71 & 11.43 \\
\hline & \multicolumn{5}{|c|}{ Jumlah } & 60.01 \\
\hline & \multicolumn{5}{|c|}{ Rata - rata } & 10.01 \\
\hline
\end{tabular}

Tabel 6. Aktifitas Selama Tindakan Siklus II

\begin{tabular}{|c|c|c|c|c|c|c|}
\hline \multirow[b]{2}{*}{ No } & \multirow[b]{2}{*}{ Aktifitas yang dilakukan } & \multicolumn{4}{|c|}{ SIKLUS II } & \multirow[b]{2}{*}{$\begin{array}{c}\text { Peningkatan } \\
(\%)\end{array}$} \\
\hline & & $\begin{array}{l}\text { Pertemua } \\
\text { n } 1\end{array}$ & $(\%)$ & $\begin{array}{l}\text { Pertemua } \\
\text { n } 2\end{array}$ & $(\%)$ & \\
\hline 1 & Mengemukan pendapat & 12 & 34.29 & 15 & 42.86 & 8.57 \\
\hline 2 & Bertanya & 15 & 42.86 & 20 & 57.14 & 14.28 \\
\hline 3 & Berdebat & 10 & 28.57 & 16 & 45.71 & 17.14 \\
\hline 4 & Memecahkan masalah & 20 & 57.14 & 24 & 68.57 & 11.43 \\
\hline 5 & Diskusi & 15 & 42.86 & 20 & 57.14 & 14.28 \\
\hline \multirow[t]{3}{*}{6} & Memberi saran & 16 & 45.71 & 19 & 54.29 & 8.58 \\
\hline & \multicolumn{5}{|c|}{ Jumlah } & 74.28 \\
\hline & \multicolumn{5}{|c|}{ Rata - rata } & 12.38 \\
\hline
\end{tabular}


Observasi dilaksanakan dengan cara mengamati seluruh aktifitas siswa selama proses pembelajaran berlangsung. Untuk aktifitas belajar siswa dilakukan dengan pensekoran berdasarkan aktifitas-aktifitas yang mencul dengan cara menghitung prosentasi dari setiap aktifitas selama pembelajaran dengan total skor $100 \%$. Aktifitas tersebut diobservasi setiap 10 menit sekali selama pembelajaran. Setelah selesai pelaksanaan pembelajaran dengan tutor sebaya dilanjutkan dengan menghimpun pendapat pendapat siswa tentang kegiatan belajar dengan metode tersebut. Pendapat siswa tersebut dikumpulkan dengan menggunakan angket.
Pengelolaan angket sikap siswa terhadap metode pembelajaran tutor sebaya dengan menggunankan skala likert. Pada angket ini disediakan 10 pertanyaan yang harus dijawab oleh siswa sesuai yang dirasakan oleh hati dan pikirannya. Tentang pelaksanaan metode pembelajaran tersebut yaitu menjawab setuju (S) mendapat skor 4, menjawab ragu, mendapat skor 3, menjawab tidak setuju (TS) mendapat skor 2, dan menjawab sangat tidak setuju (STS) mendapat skor 1. sedangkan pertayaan-pertanyaan yang diberikan adalah tercantum dalam tabel 7 , sebagai berikut :

Tabel 7. Pertanyaan Angket Siswa

\begin{tabular}{|c|l|c|c|c|}
\hline NO & \multicolumn{1}{|c|}{ PERTANYAAN } & S & TS & STS \\
\hline 1 & Metode tutor sebaya lebih mudah dipahami dalam pembelajaran & 25 & 8 & 2 \\
\hline 2 & Metode tutor sebaya lebih memotivasi siswa dalam belajar & 30 & 3 & 2 \\
\hline 3 & Metode tutor lebih menyenangkan & 30 & 3 & 2 \\
\hline 4 & Belajar dengan metode sebaya leih mudah dimengerti & 32 & 3 & 1 \\
\hline 5 & Metode tutor sebaya lebih efektif digunakan dalam kegiatan belajar & 25 & 6 & 4 \\
\hline 6 & Metode tutor sebaya dapat meningkatkan minat belajar siswa & 28 & 6 & 1 \\
\hline 7 & Metode tutor sebaya dapat meningkatkan nilai ulangan siswa & 30 & 4 & 1 \\
\hline 8 & $\begin{array}{l}\text { Metode tutor sebaya baik digunakan oleh guru untuk meningkatkan } \\
\text { efektifitas belajar }\end{array}$ & 30 & 3. & 2 \\
\hline 9 & Metode tutor sebaya perlu dilaksanakan & 29 & 4 & 2 \\
\hline 10 & Metode tutor sebaya dapat meningkatkan kemandirian siswa & 32 & 2 & 1 \\
\hline
\end{tabular}

\section{Analisis Data dan Pembahasan}

Memperhatikan hasil observasi pelaksanaan tindakan pada siklus I yang telah dilaksanakan, maka dapat dikemukakan temuan sebagai berikut :

1. Aktifitas siswa terutama dalam diskusi kelompok pada saat pemberian Lembar Kegiatan Siswa berisi soal-soal yang harus diselesaikan bersama dengan bimbingan tutornya belum sesuai target yang diingingkan dimana siswa/tutor belum terbiasa melakukan diskusi dan selalu bekerja sendiri-sendiri.

2. Dari hasil tes siklus I masih terdapat siswa yang belum mencapai kompetensi ataupun meiliki nilai dibawah standar berjumlah 22 orang, rata-rata siswa tersebut lemah menghitung atau menentukan bilangan oksidasi suatu unsur dalam senyawa.

3. Pengamatan terhadap guru kurang jelas dengan dibagian belakang, memonitor secara tidak keseluruhan hanya pada kelompok tertentu saja. Setelah memperhatikan observasi pada siklus II maka dapat dikemukakan temuan sebagai berikut: tutor sudah berantusias menjelaskan pada anggota kelompoknya, mereka berani bertanya berulang-ulang meskipun untuk satu pertanyaan yang sama selama mereka belum menguasai, mereka tidak merasa canggung, malu. Pada saat diskusi kelas berjalan dengan baikk dan lancar, pertanyaan-pertanyaan, mempertahankan pendapat, mendebatkan sebagaimana diharapkan dalam diskusi telah muncul. Guru telah merubah sesuai apa yang disarankan pada refleksi awal rata-rata aktifitas belajar siswa $60 \%$ pada siklus I, naik menjadi $74 \%$. Hasil belajar siswa yang telah lulus 18 orang (51\%) pada siklus I menjadi 30 orang (85\%) pada siklus 2 mengenai hasil rata-rata belajar siswa secara klasik mengalami peningkatan. Jumlah siswa yang lulus antara siklus I dan II yaitu siklus satu $51 \%$ dan siklus dua $85 \%$ sehingga jumlah yang lulus dari 18 orang menjadi 30 orang. Rata-rata nilai meningkat 
62.43 pada siklus pertama menjadi 7.29 pada siklus kedua.

Pada setiap siklus telah mencapai Indikator keberhasilan yang telah ditetapkan yaitu aktifitas siswa harus mencapai $70 \%$ sementara hasil belajar 75\%. Namun jika mengacu pada ketuntasan belajar secara klasik belum mencapai target dimana hasil belajar harus mencapai ketuntasan $85 \%$. Sikap siswa terhadap metode pembelajaran tutor sebaya diketahui dengan melalui angket. Dari sejumlah pertanyaan-pertanyaan yang diajukan kepada siswa melalui lembar questioner dari 35 orang responden rata-rata kelas menunjukan sikap positif yaitu antara setuju $(83,14 \%)$, tidak setuju $(12,00 \%)$ terhadap metode pembelajaran tersebut yang sangat tidak setuju $(6,57 \%)$. Dengan demikian dapat dikatakan bahwa hampir seluruh siswa merasa senang jika diberikan sebagai upaya untuk memperbaiki aktifitas dan hasil belajar siswa pada materi reaksi redoks kelas X-MIPA5 SMA Negeri 1 Sibolga.

Hasil penelitian ini diperoleh dari data mengenai rata-rata aktifitas belajar siswa mengalami peningkatan antara siklus I dan silus II sejumlah 14\%. Siklus pertama adalah $60 \%$ dan $74 \%$ pada siklus kedua. Pada siklus pertama dan siklus kedua menunjukkan bahwa aktifitas siswa secara keseluruhan mengalami peningkatan. Dari aktifitas siswa diobservasi, kegiatan-kegiatan yang tidak muncul pada pembelajaran klasikal seperti keberanian bertanya pada guru, berdiskusi, bertanya pada teman, mempresentasikan, menyatakan pendapat, berdebat sekarang menjadi nampak. Hal ini menunjukkan bahwa pembelajarn dengan menggunakan tutor sebaya dapat meningkatkan aktifitas belajar siswa model belajar tutor sebaya.

\section{KESIMPULAN}

sebagai berikut :

Simpulan yang dapat dikemukan

a. Pembelajaran tutor sebaya dapat memeperbaiki aktifitas belajar siswa. Hasil dari observasi terhadap seluruh aktifitas siswa pada siklus I dan siklus II menunjukkan rata-rata aktifitas siswa mengalami peningkatan.

b. Pembelajaran tutor sebaya dapat memperbaiki hasil belajar siswa. Hasil dari analisis terhadap nilai rata-rata kelas berdasarkan perbandingan antara kelompok pada siklus I dan siklus II dan anlisis terhadap nilai individu siswa yang diperoleh dari tes akhir pembelajarn mengalami peningkatan

\section{DAFTAR PUSTAKA}

Arikunto, S. (2005). Dasar - Dasar Evaluasi Pendidikan (Edisi Revisi). Bumi Aksara Jakarta

Arikunto, S , dkk. (2006). Penelitian Tindakan Kela. Jakarta : Bumi Aksara

Ardiana L. (2003). Penelitian Tindakan Kelas, Direktorat Pendidikan Lanjutan Pertama, Direktorat Jenderal Pendidikan dasar dan menengah, Departemen Pendidikan Nasional

Depdiknas. (2003). Penelitian Tindakan Kelas, Jakarta, Direktorat Jendral Pendidikan dasar dan Menengah, Direktorat Tenaga Kependidikan

Dikdesmen. (2003). Pemebelajaran Remedial, Jakarta. Direktorad Jendral Pendidikan dasar dan Menengah. Direktorat Tenaga Kependidikan

Engkoswara. (1994). Dasar-dasar Metodologi Pengajaran PT Aksara Jakarta

Hamalik O. (2005). Kurikulum dan pembelajaran, Bumi Aksara Jakarta

Mulyana E, (2002). Kurikulum Berbasisi Kompetensi, bandung, Rosda Karya

Sabri, A. (2005). Startegi Belajar Mengajar Mikro Teaching. Quantum teaching Jakarta

Sudirman. (1997). Ilmu Pendidikan, Bandung, Remaja Karya 